\title{
Mauna Kea - Construction Site or Sacred Land? A Look at the Long-lasting Effects of the Hawaiian Annexation
}

\section{Emerald Naylor}

On 12 September 2015, The Economist published a news article discussing the backlash regarding the Thirty Meter Telescope (TMT) project that was planned to be built on Mauna Kea. Mauna Kea is one of six volcanoes that makes up part of Hawaii's Big Island. This volcano is also believed to be where "the native Hawaiian creation story begins" by tying the world to Wakea, the sky father. ${ }^{1}$ The cool, clear air and sheltered location makes Mauna Kea one of the best places on Earth to gaze out into space; because of this, thirteen telescopes have been built here, with the TMT being the fourteenth and largest. Since 1964, each of the thirteen prior telescopes were met with protests and political backlash. ${ }^{2}$ The TMT is a 1.4 billion dollar project backed by international astronomers, which will allow scientists to study stars up to thirteen billion light-years away. ${ }^{3}$ The TMT project would be a huge step forward for the scientific community, but it is causing deeper problems regarding land claims, history, and the incarceration of native Hawaiians. ${ }^{4}$ This telescope has stirred up Hawaiian Nationalists, some of whom have connections to Hawaii's sovereignty movement, and others who are still angry over Hawaii's annexation at the end of the nineteenth century. The TMT project has brought old and ongoing tensions between Americans and Native Hawaiians back to the attention of the public eye. Shirts with the slogan "Born Hawaiian, forced to be American" are being sold by younger

\footnotetext{
1 "Under the Volcano," The Economist (2015) http://www.economist.com/news/united-states/21664211-telescopedesigned-be-pointed-space-turned-opposite-direction-under.

${ }^{2}$ Ibid.

${ }^{3}$ Ibid.

${ }^{4}$ Ibid.
} 
generations, proving that the tensions between Native Hawaiians and Americans are not exclusive to older generations, and have not necessarily improved over the last few years. ${ }^{5}$

By looking at the TMT project and the protests and controversies that have arisen from it, the main problem seems to stem from ongoing tensions between Americans and Native Hawaiians that began prior to the annexation of Hawaii. As with any historical dilemma, there are two sides to this issue; however, the Hawaiians have largely been quieted by the larger power of the American government. It is with the construction of the TMT that Hawaii's past has been brought to the foreground. The tense relationship between the two nationalities traces back to the mid-to-late 1800s surrounding issues of trade, economics, empire expansion, and loss of culture. As stated in The Economist, the relationship between Americans and Hawaiians "adds up to an argument that looks much like Mauna Kea itself. If measured from its base, the volcano is well over six miles tall, making it easily the world's highest mountain. Yet the majority of Mauna Kea lies submerged below the warm waters of the Pacific. ${ }^{96}$ On the surface, the protests surrounding the TMT may seem as though they are about sacred land being disrespected with yet another telescope being built, but the root issues go much deeper than that. Strains in the relationship between Americans and Native Hawaiians have had long-lasting ramifications, as shown through contemporary protests about the TMT project. The cause of these protests and the tense relationship between the two nations, can be traced back to the late 1800s and the Annexation of Hawaii.

Hawaii was formally annexed to the United States of America in 1898 after many years of trade agreements and negotiations. To truly understand the repercussions the annexation had

\footnotetext{
${ }^{5}$ Ibid.

${ }^{6}$ Ibid.
} 
on Hawaii and its peoples, we must first look at Hawaii before 1890. Hawaii's culture revolved around their land, much of which was believed to be sacred. Hawaiians had different beliefs from the Europeans and eventually Americans, regarding who their land belongs to and what its purpose was. As shown in their creation story, the land in Hawaii belongs to the ancestors and the first beings of the world. The pre-Christianized Hawaii was rich in "rituals, material practices, leisure habits, and mythic/genealogical lineages" of the nobility and people of Hawaii. ${ }^{7}$ Many of these ideals were preserved and recorded in the Hawaiian Antiquities which was published in 1898 , the same year Hawaii was annexed and the natives were westernized. ${ }^{8}$

Hawaii had a long history of coming into contact with other cultures and nationalities. Many islands in the Pacific Ocean were colonized as early as 1521, but Hawaii remained isolated until the late 1700s. ${ }^{9}$ Hawaii was explored by Europeans and "their influence quickly became pervasive." ${ }^{10}$ Colonists were attracted to the islands for economic purposes, and later for political control. As was the practice of colonial powers, the Europeans introduced the Native Hawaiians to their technology: ships, iron, and weapons, such as guns. ${ }^{11}$ Natives of Hawaii were introduced to Western culture early in their existence. Hawaiians adopted some of the technological advances, but they were still able to maintain much of their culture. With American contact, it became increasingly difficult for the Native Hawaiians to hold on to their unique island culture. Hawaii became less about land worship and the rich culture that paid respect to their ancestors; instead it became a tourist destination. Americans saw Hawaii as "an imaginative topography

\footnotetext{
${ }^{7}$ Bruce Harvey, “Being Blue in Hawai'i: Politics, Affects, and the Last Queen of Hawai'i,' Journal of Transnational American Studies 3 (2011): 5, http://escholarship.org/uc/item/5rc7b51t.

${ }^{8}$ Ibid.

${ }^{9}$ Niklaus R. Schweizer, Turning Tide: The Ebb and Flow of Hawaiian Nationality. (Berlin: Internationaler Verlag der Wissenschaften, 2005), 37.

10 Ibid.

11 Ibid, 39.
} 
oddly at once exotic and blandly regional, a far-away paradise and yet just another state, that we [...] cannot see it as a colonized or occupied once sovereign nation." 12 Hawaii is still seen as a major tourist destination, even as the Hawaiians try to fight back for their culture.

Prior to the Hawaiian Annexation, Hawaii was a nation with a monarch. The Queen was the last monarch of Hawaii. She was overthrown after the American government paid off both the Queen and the Princess in order to take over the economy: "By that projet [sic] of a treaty the Queen was to be paid the sum of $\$ 20,000$ annually during her life and the Princess was to receive in hand from the United States the sum of $\$ 150,000 . " 13$ The Queen and Princess were only to be paid if they submitted to the United States' government authority. Following the overthrow, Queen Lili'uokalani tried to regain her position in hopes of restoring her nation's independence. She was fully supported by her people, but unfortunately, she was unsuccessful in her actions. ${ }^{14}$ The Queen was a maternal figure who cared for the wellbeing of her nation, and fought to protect it even after she was overthrown. Every decision Queen Lili'uokalani made during her reign was to better her nation. Bruce discusses, in his article, what happened after the annexation: "the Queen continued to plead her cause, but in 1895 she was incarcerated in her own palace, and put on trial for counter-revolutionary support of Royalists (she was released after several months, and died, in exile in her own land, two decades later)." ${ }^{15}$ Queen Lili'uokalani was a mother to Hawaii and the people there. Articles written about the annexation from Hawaii's perspective, such as Bruce's, captured the emotional pain and intensity that the Natives Hawaiians felt towards America. They believed that their Queen was treated poorly, and that the annexation was

\footnotetext{
12 Harvey, "Being Blue in Hawai'i," 14.

${ }^{13}$ Boutwell, George S. Boutwell, "Hawaiian Annexation." The Advocate of Peace 60 (1898): 19, http://www.jstor.org/stable/25751123.

${ }^{14}$ Schweizer, Turning Tide, 335.

15 Harvey, "Being Blue in Hawai'i," 11.
} 
merely a plot against the monarchy. "Aloha 'Oe" was a song composed by Queen

Lili'uokalani, which described the heartbreak she felt for the loss of her nation. This song has since been covered by Elvis Presley, making a mockery out of a turning point in Hawaiian history. ${ }^{17}$ While this song is an expression of loss for Hawaii and taken seriously by the Native Hawaiians, many felt an American singer was not able to understand the meaning behind the song. Instead it became a hit song for one of Presley's movies, and the cultural significance was erased. This is a trend that has continued in Hawaii since the annexation; America has taken a nation rich in culture and traditions, and degraded it into a tourist destination. It is this lack of respect, which has put strains on the Hawaiian-American relationship.

Similarly, many pieces of propaganda were published shortly after Hawaii was annexed, which showcased the tensions between Native Hawaiians and Americans. A cartoon released in the German edition of Puck on 1 December 1897, depicts Queen Lili'uokalani and Uncle Sam kneeling in front of a priest. The caption read: "Once again a forced wedding bringing no particular joy to either partner."18 The motivation for America's desire for and annexation of Hawaii was not always clear to the other world leaders and countries; there did not seem to be a well-known and immediate benefit to either party. Instead, America was faced with backlash from Native Hawaiians and the Hawaiian government that would continue into the present day. To understand what value America saw in the Hawaiian Islands, one must look at the late 1890s from both nations' perspectives.

\footnotetext{
16 Ibid, 12.

17 Ibid, 11.

${ }^{18}$ Charles Jay Taylor. Another shotgun wedding, with neither party willing. Keppler \& Schwarzmann, New York, December 1, 1897. Cartoon. http://www.loc.gov/pictures/item/2012647635/.
} 
The 1890s were a period of legislative battles and negotiations between Hawaii and America. The legislative session of 1892 was one of the longest in Hawaiian history. ${ }^{19}$ Queen Lili'uokalani struggled to pursue her policies; her parliament only met every two years, so she was unable to reconvene until 1894. At this time, the American government was in the process of annexing Hawaii. Based on George S. Boutwell's speech regarding the matter, there were four opportunities for annexation of different territories. ${ }^{20}$ There were many different reasons compelling America to annex one of their territories: the Hawaiian Islands, Alaska, Louisiana, California and Texas. ${ }^{21}$ Plans to expand into these territories were in motion for years before the actual annexations. In Hawaii, America had the Treaty of 1875 and the Amendment of 1887, which allowed the country full control of Hawaii's trade under the permission of Queen Lili'uokalani. Hawaii became a land of sugar, pineapples, and tourism for mainland America; both nations needed the McKinley Tariff to support their economies. ${ }^{22}$ The loss of Hawaii's sugar exports would have resulted in the loss of the free American market, and a $40 \%$ increase on the Islands' sugar products. ${ }^{23}$ While the people of Hawaii did not consent to their annexation to any country, they could not afford to abrogate the treaty with the United States. The Hawaiian government pleaded for the preservation of the treaty to prevent the nation's sugar plantations from going bankrupt. ${ }^{24}$ America, seizing an opportunity, preserved the treaty and moved forward with their plans for annexation. Boutwell declared: "All the benefits that can come from annexation are now enjoyed by us, and they will continue to be enjoyed by us and by our successors through many generations, while we now are, and they hereafter are to be relieved of

\footnotetext{
${ }^{19}$ Schweizer, Turning Tide, 284.

${ }^{20}$ Boutwell, "Hawaiian Annexation," 17.

${ }^{21}$ Ibid, 17-18.

${ }^{22}$ Ibid.

${ }^{23}$ Ibid, 19.

${ }^{24}$ Ibid.
} 
all responsibility for the government of the Islands." 25 Hawaii was to be annexed; the Americans reveled in their own success without thinking of the long-term causes for the Native Hawaiians. As evident in the TMT protests, Hawaii's annexation would cause tensions, lasting into the contemporary era, between the Native Hawaiians and the Americans.

Though one of the reasons for Hawaii's annexation had to do with sugar exports and the protection of both nations' economies, America also had imperial expansion in mind. The Hawaiian Islands, located in the middle of the Pacific, appealed to America in terms of expanding their empire as they hoped to reach across to Asia. America's relationship with imperialism and empires is an interesting one. The United States can most accurately be described as an "empire in denial," meaning that they intervene, "in the affairs of foreign peoples and [underestimate] the benefits of doing so." 26 The American empire is like no other, mainly because of its refusal to identify as an empire. William Henry Seward, an American politician who imagined the best for the empire, believed that the Hawaiian Islands could be the outposts to help spread American products and ideals to Asia and the rest of the world. ${ }^{27}$ With California as the newest state, Seward wanted to expand across the Pacific Ocean. He wanted what he called the "distant islands" of both the Pacific Ocean and Caribbean Sea to be part of America's empire. ${ }^{28}$ Seward saw prosperity for America as a result of expanding towards Asia. He believed that "Asia was the greatest 'prize' and 'the chief theater of events in the world's great hereafter." 29 With that goal in mind, the Treaty of Annexation of Hawaii was drawn up in 1894, where it laid as a document for a while. Hawaii was America's "economic colony" and held

\footnotetext{
25 Ibid.

${ }^{26}$ Richard H. Immerman, Empire for Liberty: A History of American Imperialism from Benjamin Franklin to Paul Wolfowitz (New Jersey: Princeton University Press, 2010), 4.

${ }^{27}$ Ibid, 129.

${ }^{28}$ Ibid, 114.

29 Ibid.
} 
great future commercial progression. ${ }^{30}$ The annexation would allow the United States to have full control of Hawaii's economy and government; it would also prevent Britain or Japan from snatching the islands up for their own imperial gain. ${ }^{31}$

Following Britain's example, America set out to create territories that would be able to do their fighting off of the main land. The Hawaiian Islands were desirable as a war buffer for America - the people were not as important to them as was the land itself. More specifically, it was the harbour at the mouth of Pearl River that the Americans wanted. This harbour would allow Americans to have access to the Pacific Ocean, and allow them to expand their trade into Asia. In 1887, the United States were able to acquire Pearl River Harbour, the most valuable harbour on the islands. ${ }^{32}$ Before the annexation, Hawaii was free to use the harbour to interact with other nations, much like Britain allowed their colonies to interact with each other. Hawaii also acted as a security buffer for America; its closest neighbour was California. Should a war in the Pacific Ocean break out, it would be far enough from the mainland. America's view of Hawaii as a war buffer zone, and part of imperial expansion, did not help to ease the conflicts between Americans and Native Hawaiians. While the annexation was exactly what the United States wanted, it pushed a wedge in their relationship with Hawaii. This relationship is one that has continued to be tense up to the present day.

These underlying tensions between Native Hawaiians and Americans were created with the plans to annex Hawaii in the 1890s. Since then, Hawaiians have felt as though their land and culture has been disrespected by the United States. The TMT project is just one of the more popular contemporary instances where this old strained relationship is brought back to the

\footnotetext{
${ }^{30}$ Ibid, 138.

${ }^{31}$ Ibid, 140.

${ }^{32}$ Boutwell, "Hawaiian Annexation," 19.
} 
foreground. Within the last year, protests opposing the TMT have become stronger and more divisive than ever before because of the Native Hawaiian pride that is sweeping the nation. ${ }^{33}$ These protests have been used as a tool to teach tourists and visitors of Hawaiian culture and traditions; this is something that we have not seen in prior telescope protests. The opposition towards the TMT project has "tapped into broader anger against the US government and its past behaviour towards the islands and their native peoples." 34 These protests have become about much more than blocking the road to the construction site; they have acted as a way for the Hawaiians to fight back against the loss of their culture and what was taken from them a few centuries ago. The Hawaiian culture was largely suppressed for decades, but the younger generations have taken it upon themselves to fight for their nation and protect their culture: "We are fighting for the rights of the mountain [...] I have nothing against astronomy - just don't put it up there." ${ }^{35}$ Joshua Lanakila Mangauil, one of the avid protestors, explains that this is not a protest against the advancement of astronomy itself; it is a way for him to protect his culture and have a voice against the US government.

The future for Hawaii and the TMT project is still uncertain. This is an issue that is still unfolding today as years of tension and strain between Native Hawaiians and Americans boil over. The construction has been put on hold because of the ongoing protests. Recently, the governor of Hawaii, David Ige, has called for the closing of a quarter of the thirteen telescopes that already reside on Mauna Kea. ${ }^{36}$ Ige has given the approval for the TMT construction to

\footnotetext{
${ }^{33}$ Alexander Witze, “Mountain Battle,” Nature 526 (2015): 24, doi: 10.1038/526024a.

${ }^{34}$ Ibid.

35 Ibid, 25.

${ }^{36}$ Adrian Cho, "Affirming support for Thirty Meter Telescope, Hawaii's governor calls for closing others," ScienceMag (2015), doi: 10.1126/science.aac4654.
} 
proceed, but he has declared that "all future telescopes must be built on existing sites." 37 This is an attempt to protect what is left of the sacred land, while still pleasing the astronomers behind this project.

In conclusion, the history behind the protests of the TMT project is long and complicated, but really stems from the Hawaiians' desire to protect their nation and culture. The underlying cause for the protests and the tense relationship between Native Hawaiians and Americans can be traced back to the late 1800 s and the Hawaiian Annexation. Leading up to the annexation, both nations' economies were relying on one another for growth and success. The United States took advantage of the mutual need for the trade agreement, and planned to annex Hawaii as a way to expand their empire across the Pacific Ocean and into Asia. In response, Hawaii, led by Queen Lili'uokalani, fought to regain control over their government and their culture. These early disputes have led to many more taking place throughout the twentieth and twenty-first centuries. To this day, relationships between Native Hawaiians and Americans remain tense. New issues are being brought to the public's attention with the help of social media and a younger generation willing to use their voice. The TMT project will be an interesting development to watch as Hawaii continues to fight for their culture and their land.

\footnotetext{
${ }^{37}$ Korey Hayes, "The Future of Hawaiian Astronomy," Canadian Periodicals Index Quarterly 43 (2015): 16, http://go.galegroup.com/ps/i.do?id=GALE\%7CA425110765\&v=2.1\&u=wate34930\&it=r\&p=CPI\&sw=w\&asid=1a9 ddbe7c463ba133e13df2691bb4ea0
} 


\section{Bibliography}

Boutwell, George S. "Hawaiian Annexation." The Advocate of Peace 60, no. 1 (January 1898): 17-20. http://www.jstor.org/stable/25751123.

Chang, David A. "'We Will Be Comparable to the Indian Peoples": Recognizing Likeness between Native Hawaiians and American Indians, 1834-1923." American Quarterly 67, no. 3 (September 2015): 859-86. https://muse.jhu.edu/.

Cho, Adrian. "Affirming support for Thirty Meter Telescope, Hawaii's governor calls for closing others." ScienceMag, May 27, 2015. doi: 10.1126/science.aac4654.

Feder Lee, Anne, and Norman Meller. "Hawaiian Sovereignty." The Journal of Federalism 27, no. 2 (Spring 1997): 167-85. http://publius.oxfordjournals.org/.

Haley, James L. Captive Paradise: A History of Hawaii. New York: St. Martin's Press, 2014.

Harvey, Bruce. "Being Blue in Hawai'i: Politics, Affects, and the Last Queen of Hawai'i." Journal of Transnational American Studies 3, no. 2 (December 1, 2011): 1-25. http://escholarship.org/uc/item/5rc7b51t.

Haynes, Korey. "The Future of Hawaiian Astronomy." Canadian Periodicals Index Quarterly 43, no. 9 (September 2015): 16. http://go.galegroup.com/ps/i.do?id=GALE\%7CA425110765\&v=2.1\&u=wate34930\&it=r $\& \mathrm{p}=\mathrm{CPI} \& \mathrm{sw}=\mathrm{w} \& \mathrm{asid}=1 \mathrm{a} 9 \mathrm{ddbe} 7 \mathrm{c} 463 \mathrm{ba} 133 \mathrm{e} 13 \mathrm{df} 2691 \mathrm{bb} 4 \mathrm{ea} 0$.

Immerman, Richard H. Empire for Liberty: A History of American Imperialism from Benjamin Franklin to Paul Wolfowitz. New Jersey: Princeton University Press, 2010.

Osborne, Thomas J. "The Main Reason for Hawaiian Annexation in July, 1889." Oregon Historical Quarterly 71, no. 2 (June 1970): 161-78. http://www.jstor.org.proxy.lib.uwaterloo.ca/stable/20613162.

Schweizer, Niklaus R. Turning Tide: The Ebb and Flow of Hawaiian Nationality. 3rd ed. Berlin: Internationaler Verlag der Wissenschaften, 2005.

Silva, Noenoe K. Aloha Betrayed: Native Hawaiian Resistance to American Colonialism. London: Duke University Press, 2004, doi: 10.1215/9780822386223.

Taylor, Charles Jay. Another shotgun wedding, with neither party willing. Keppler \& Schwarzmann, New York, December 1, 1897. Cartoon. http://www.loc.gov/pictures/item/2012647635/.

Witze, Alexandra. "The mountain-top battle over the Thirty Meter Telescope." Nature 526, no. 7571 (September 29, 2015): 24-28, doi: 10.1038/526024a.

"Under the Volcano." The Economist, September 12, 2015. http://www.economist.com/news/united-states/21664211-telescope-designed-be-pointedspace-turned-opposite-direction-under. 